\title{
Antalya'da Küçükbaş Hayvancılıkta Sürdürülebilirliğe Etki Eden Ekonomik Faktörlerin Değerlendirilmesi
}

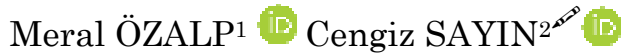 \\ ${ }^{1}$ Akdeniz Üniversitesi, Kumluca Meslek Yüksekokulu, Muhasebe ve Vergi Uygulamaları Bölümü, Antalya, ${ }^{2}$ Akdeniz Üniversitesi, Ziraat \\ Fakültesi Tarım Ekonomisi Bölümü, Antalya \\ 凹: csayin@akdeniz.edu.tr
}

\section{ÖZET}

Bitkisel ve hayvansal gıda talebi nüfus artışına bağlı olarak artış göstermektedir. Antalya ili sahil bandı örtü altı üretimi ve turizm sektörü açısından elverişlidir. Buna karşın, yayla bandında yer alan bölgeler hayvancılık için uygun bir ortam sağlamaktadır. Turizm sezonunda kent, nüfusunun üstünde nüfus ağırladığından, bitkisel ve hayvansal gıda talebinde de artış yaşanmaktadır. Buna bağlı olarak, kentin artan hayvansal gıda talebinin karşılanmasında hayvansal üretim önem kazanmaktadır. Antalya'da koyun ve keçi yetiştiriciliğinin hayvansal üretim içerisinde belirgin bir payı vardır. Küçükbaş hayvancılık, süt ve süt ürünleri ile et üretimi bakımından sahil bandında artan hayvansal gıda ihtiyacının önemli bir bölümünü karşılamaktadır. Ancak, bunun sürdürülebilir olması açısından ekonomik etkenlerin beklentileri karşılaması gerekmektedir. Küçükbaş hayvancılıkta sürdürülebilirlik; pek çok ekonomik, kültürel, politik ve sosyo-ekonomik faktörden etkilenmektedir. Bu nedenle, küçükbaş hayvancılıkta sürdürülebilirliğe etki eden ekonomik faktörlerin incelenmesi izlenecek politikaların kurgulanması aşamasında önem taşımaktadır. $\mathrm{Bu}$ doğrultuda, bu çalışmada Antalya ili örneğinde küçükbaş hayvancıllk süt üretim faaliyetinde sürdürülebilirliğe etki eden ekonomik faktörlerin değerlendirilmesi amaçlanmıştır. Çalışmanın ana materyalini Antalya ilinde damızlık küçükbaş hayvan işletmelerinden yüz yüze anket yolu ile elde edilen orijinal (birincil) veriler oluşturmaktadır. Alan araştırması Batı Akdeniz Bölgesi'nde gerçekleştirilmiş, örnekleme yöntemi olarak tabakalı örnekleme metodu kullanılmıştır. Batı Akdeniz Bölgesi'nde gerçekleştirilen araştırma kapsamında 3 ilde toplam 151 anket yapılmış, bu çalışmada sadece Antalya ilinde gerçekleştirilen 72 anket kullanılmıştır. Araştırma dönemi 2016 Ekim ve 2017 Eylül arasını içeren 1 yıllık dönemi kapsamaktadır. Elde edilen sonuçlara göre Antalya'da küçükbaş hayvancılık süt üretimi faaliyetinde yem masrafları \% 40 'lık payı ile en büyük masraf kalemini oluşturmaktadır. Antalya'da küçükbaş hayvancılık süt üretiminin ekonomik olarak sürdürülebilirliğini sağlamak için süt üretimi gelirini artıracak ve yem masraflarını azaltacak önlemlerin alınması ve yetiştiricilerin daha fazla destekleme kaleminden yararlanabilmesi için gerekli düzenlemelerin yapılması gerekmektedir.
Makale Tarihçesi

Geliş : 20.10.2018

Kabul : 26.12.2018

Anahtar Kelimeler

Küçükbaş Hayvancılık,

Sürdürülebilirlik,

Antalya

\section{Araștırma Makalesi}

\section{Evaluation of Economic Factors Affecting Sustainability of Small Ruminant Breeding in Antalya}

\section{ABSTRACT}

The demand for vegetable and animal food is increasing due to population growth. The coastal belt of Antalya province is appropriate in terms of livestock production and tourism sector. On the other hand, the region's plateau provides a suitable environment for animal breeding. As the city welcomes a population greater than its own population during the tourism season, the demand for vegetable and animal food is also increasing. Accordingly, animal production gains importance in meeting the increasing demand for animal food in the

\section{Article History}

Received : 20.10 .2018

Accepted : 26.12.2018

\section{Keywords}

Small ruminant breeding,

Sustainability,

Antalya

Research Article 
city. In Antalya, sheep and goat breeding have a significant share in animal production. Sheep breeding meets a significant portion of the animal's food needs in the coastal belt in terms of milk, milk products and meat production. However, in terms of sustainability, it is necessary for economic factors to meet expectations. Sustainability in livestock breeding influenced by many economic, cultural, political and socio-economic factors. For this reason, examining the economic factors affecting sustainability in livestock breeding is crucial in the development of policies to be implemented. In this respect, in this study, it is aimed to evaluate the economic factors affecting sustainability of milk production of goat and sheep breeding in Antalya. The main material of the study was the original (primary) data obtained from face-to-face surveys from small ruminant breeders in Antalya. The field research was carried out in the Western Mediterranean Region and the stratified sampling method was used for sampling. A total of 151 questionnaires were conducted in 3 provinces of the Western Mediterranean Region, and 72 questionnaires were used in only Antalya. The research was conducted for 1 year covering from October of 2016 to September 2017. Results indicated that feed costs in milk production activity of small ruminant breeding in Antalya constitutes the biggest expense item with a share of $40 \%$. In order to ensure the economic sustainability of milk production of small ruminant breeding in Antalya, it is necessary to take measures to increase milk production income and to reduce feed costs and to make necessary arrangements for the breeders to benefit from.

To cite: Özalp M, Sayın C 2018. Antalya'da Küçükbaş Hayvancılıkta Sürdürülebilirliğe Etki Eden Ekonomik Faktörlerin Değerlendirilmesi. KSÜ Tar Doğa Derg 21(Özel Sayl) : 1-11, DOI : 10.18016/ ksutarimdoga.vi.472776.

\section{GİRIŞ}

Bruntland Raporu'nda sürdürülebilir kalkınma; gelecek nesillerin ihtiyaçlarını karşılama yeteneğini riske atmadan bugünün ihtiyaçlarını karşılayan kalkınma olarak tanımlanmaktadır (Anonim, 1987).Buna bağlı olarak sürdürülebilir hayvancılık, hayvancılığın var olması için gerekli kaynakların korunarak gelecek nesillere aktarılması, hayvansal arz ve talebin sürekliliğinin sağlanmasına çalışılması olarak ifade edilebilir. Sürdürülebilir kalkınmanın ekonomik, sosyal ve çevresel olmak üzere üç boyutu bulunmaktadır. Çevresel sürdürülebilirlik, işletme faaliyetlerinin çevresel etkilere karşı duyarlı olması, sosyal sürdürülebilirlik ise işletmenin çalışanlarına topluma ve tüm paydaşlarına karşı sorumlu davranması, ekonomik sürdürülebilirlik ise işletmenin faaliyetlerinin ulusal ve uluslararası ekonomiye etkileri olarak açıklanabilir (Aracı ve Filiz; 2016). Bu çalışma kapsamında ekonomik sürdürülebilirlik dikkate alınmıştır.

Tarımsal üretim iklim koşulları, tarımsal ürünlerdeki fiyat dalgalanmaları, kar marjının düşük olması, enerji ve yem fiyatlarında dışa bağımlılık gibi nedenlerden dolayı küçülmektedir (Anonim, 2010).Tarımsal üretimin artırılması, buna paralel olarak talebin de artırılması ile tarımsal faaliyetin hacmi arttırılabilmektedir(Doğan ve Kızıloğlu, 2013).Ancak tarım işletmelerinin pazar koşullarına ayak uydurma zorunluluğu, teknolojik gelişmeler işletme yönetimini daha karmaşık hale getirmektedir(Bozoğlu ve ark., 2001).Bu nedenle işletmelerin başarısını etkileyen faktörler arasında verimlilik düzeyi, rekabet gücü ve işletmelerin yapısal ve ekonomik analizinin yapılması önem kazanmaktadır (Karagölge, 2001).

Antalya ilinde yayla bandında yer alan bölgeler hayvancılık için, özellikle küçükbaş hayvancılık yetiştiriciliğinde izlenen yaylacılık tarzı üretim şekli için uygun bir ortam sağlamaktadır. Turizm sezonunda kent nüfusunun üstünde nüfus ağırladığından, bitkisel ve hayvansal gida talebinde de artış yaşanmaktadır. Buna bağlı olarak, kentin artan hayvansal gida talebinin karşılanmasında hayvansal üretim önem kazanmaktadır. Küçükbaş hayvancılık, süt ve süt ürünleri ile et üretimi bakımından sahil bandinda artan hayvansal gida ihtiyacının bir bölümünü karşılamaktadır. Ancak, bunun sürdürülebilir olması açısından ekonomik etkenlerin beklentileri karşılaması gerekmektedir. İşletmelerin üretim faaliyetlerine devam etmeleri için temel ekonomik etkenlerden biri kar elde etmeleri ve karlılığın işletmeler açısından sürdürülebilir olmasıdır. Dolayısıyla karlılığın hangi ekonomik faktörlerden etkileneceği önem taşımaktadır. Bu çalışmanın amacı Antalya ilinde küçükbaş hayvancılık süt üretimi faaliyeti açısından ekonomik 
sürdürülebilirliğe etki eden faktörlerin değerlendirilmesidir.

Kar elde etmek isteyen işletmeler maliyetlerini minimum düzeyde, satış gelirlerini ise maksimum seviyede tutmak isterler. Bu doğrultuda bu çalışmada öncelikle saha araştırması sonucu küçükbaş hayvan yetiştiricilerinden elde edilen verilere dayanılarak küçükbaş hayvancılık işletmelerinde süt üretim geliri ve masraf unsurları inceleme konusu olmuştur. Küçükbaş hayvancılık süt üretimi karını etkileyen verimlilik düzeyi, süt geliri ile masraf kalemleri, hem işletme büyüklüklerine göre hem de koyun, keçi yetiştiriciliği ayrımında incelenmiştir.

\section{MATERYAL ve METOT}

\section{Materyal}

Çalışmanın ana materyalini Antalya ilinde damızlık küçükbaş hayvan işletmelerinden yüz yüze anket yolu ile elde edilen orijinal (birincil) veriler oluşturmaktadır. Bu çalışmada Akdeniz Üniversitesi Bilimsel Araştırma Projeleri Koordinasyon Merkezi(BAP)tarafindan desteklenen FDK-2017-2599 no'lu "Damızlık Küçükbaş Hayvancılıkta Destekleme Politikalarının İşletmelere Etkisi Batı Akdeniz Bölgesi Politika Analizi Matrisi Yaklaşımı " başlıklı Doktora Tez Projesi kapsamında gerçekleştirilen anket çalışması ile elde edilen veriler kullanılmıştır. Proje kapsamında gerçekleştirilen saha araştırması Batı Akdeniz Bölgesi'ni kapsamaktadır. Ancak bu çalışmada Antalya ilinde gerçekleştirilen anketler ile elde edilen birincil veriler kullanılmıştır. Araştırma dönemi 2016-Ekim ve 2017-Eylül arasını içeren 1 yıllık dönemi kapsamaktadır.

Anket kapsamında küçükbaş hayvancılık sektöründe süt üretiminin gelir ve maliyet unsurlarına ilişkin sorular sorulmuştur. Çalışmada Birleşmiş Milletler Gıda ve Tarım Örgütü (FAO), Türkiye İstatistik Kurumu (TÜIK) ve Gıda, Tarım ve Hayvancılık Bakanlığı ile diğer ikincil veri kaynakları, indekslerce taranan ve taranmayan yayınlardan, raporlardan ve tez çalışmalarından da yararlanılmıştır.

\section{Metot}

\section{Veri toplama metodu}

Batı Akdeniz Bölgesi süt üretim faaliyetinin ekonomik yapısının ortaya çıkarılması için temel olan veriler orijinal (birincil) veriler olup süt üretimi yapan küçükbaş hayvan yetiştiricilerinden, birebir ve yüz yüze görüşmeye dayalı anket uygulaması ile elde edilmiştir.

Isparta ve Burdur Damızlık Koyun Keçi yetiştiricileri birliği ve Antalya Tarım İl Müdürlügü’nden elde edilen verilere göre Isparta'da 12 ilçede 2451 işletmede, Burdur'da 14 ilçede 1977 işletmede ve Antalya'da 19 ilçede 4184 işletmede olmak üzere Batı Akdeniz
Bölgesi'nde toplam 45 ilçede 8611 işletmede damızlık koyun- keçi yetiştiriciliği yapılmaktadır. Buna göre, Batı Akdeniz Bölgesi'nde yer alan koyun-keçi yetiştiricilerinin yaklaşık \%48'i Antalya'da, \% 29'u Isparta'da ve \%23 'ü Burdur'da yer almaktadır (Anonim 2014a,Anonim 2014b,Anonim 2014c).

Batı Akdeniz Bölgesi’nde faaliyet gösteren 8611 damızlık koyun keçi yetiştiricisinin oluşturduğu popülasyonu temsil edebilecek uygun örneklem genişliğinin hesaplanabilmesi için öncelikle uygun örneklem tekniğinin seçilmesi gerekmektedir. Bu çalışmada işletmeleri büyüklüklerine göre ayırmak amacı ile işletmelerin hayvan varlığı örneklem birimi olarak seçilmiştir. Normal dağılım testi ile popülasyonu oluşturan birimlerin normal dağılım göstermediği saptanmıştır. Homojen özellikte olmayan popülasyon verileri ile elde edilecek sonuçların tutarlı olmayacağı göz önünde bulundurularak "tabakalı örnekleme yöntemi"ile örnek hacminin belirlenmesine karar verilmiştir. İşletmeler hayvan varlığ 1 esas alınarak 3 tabakaya ayrılmıştır. Aşırı uç değerler göz ardı edilmiş buna bağlı olarak gözlem sayısı 8601'e inmiştir. Popülasyonun tümüne ve her tabakaya ait varyans ve ortalamalar esas alınarak, ortalamadan $\% 5$ hata payı ve \%95 güven sinırlarına göre örnek büyüklüğü 122 olarak hesaplanmıştır. Hesaplanan örnek büyüklügünün \% 20 'si kadar yedek anket doldurulmasına karar verilmiştir. Buna bağlı olarak yapılacak anket sayısı 145 olarak belirlenmiştir.

Örnek hacmi Tabakalı Örnekleme ile Neyman Yöntemine göre aşağıda belirtilen formül yardımıyla hesaplanmıştır (Yamane, 1967).

$$
n=\frac{\left(\sum N_{h} S_{h}\right)^{2}}{N^{2} D^{2}+\sum N_{h} S_{h}^{2}}
$$

n: Örnek hacmi

$\mathrm{N}$ : Popülasyondaki işletme sayısı

Nh: h'ninci tabakadaki işletme sayısı

Sh: h' ninci tabakanın standart sapması

$$
D^{2}=\frac{d^{2}}{Z^{2}}
$$

d: Popülasyon ortalamasından izin verilen sapma (hata miktarı)

Z: İzin verilen güvenlik sınırlarının z dağılım tablosundaki değeri $(\mathrm{Z}=1,96)$

Örnek hacminin tabakalara dağıtılmasında aşağıdaki eşitlikten yararlanılmıştır (Yamane, 1967).

$$
n_{h}=\frac{N_{h} S_{h}}{\sum N_{h} S_{h}} n
$$

Örneklemin tabakalara göre frekans dağılımı ve örnek büyüklüğü ve yapılması planlanan anket sayısı Çizelge 1'de verilmektedir. 
Çizelge 1.Tabakalı örnekleme yöntemine göre hesaplanan örnek büyüklü̆̆̈u

\begin{tabular}{|c|c|c|c|c|c|}
\hline $\begin{array}{l}\text { İşletme } \\
\text { Grupları }\end{array}$ & $\begin{array}{c}\text { Tabaka } \\
\text { Sinırları } \\
\text { (Hayvan adedi) }\end{array}$ & Frekans & Varyans & $\begin{array}{c}\text { Örnek } \\
\text { Büyüklüğ̈ü }\end{array}$ & $\begin{array}{c}\text { Yapılacak } \\
\text { Anket sayısı } 1\end{array}$ \\
\hline I & $\leq 124$ & 5203 & 819.343 & 56.9 & 68 \\
\hline II & $125-249$ & 2387 & $1,196.474$ & 31.5 & 38 \\
\hline III & $\geq 250$ & 1011 & $6,050.896$ & 33.03 & 39 \\
\hline Toplam & - - - - & 8601 & - & 122 & 145 \\
\hline
\end{tabular}

Batı Akdeniz Bölgesi'nde gerçekleştirilen anket çalışmasında 3 ilde toplam 151 anket yapılmış, anketlerin 75 'i, yani yaklaşık \%50'si Antalya ilinde gerçekleştirilmiş, bunlardan 3 ‘ü uç değerler içerdiği için analizden çıkarılmıştır. Antalya ili için toplamda 72 anket çalışmaya dâhil edilmiştir. Çizelge 2'de anketlerin ilçelere göre dağılımı verilmektedir. Anketler keçi ve koyun yetiştiriciliğinin en yoğun yapıldığı Manavgat, Elmalı ve Korkuteli ilçelerinde gerçekleştirilmiştir. Antalya ili için toplam anket sayısı oransal olarak tabakalara dağıtılmıştır.

Çizelge 2.Antalya'da yapılan anketlerin ilçelere göre dağılımı

\begin{tabular}{|c|c|c|c|c|}
\hline & \multicolumn{3}{|c|}{ İşletme gruplarına Göre Anket Sayıları (adet) } & \multirow[b]{2}{*}{$\begin{array}{l}\text { Toplam Anket } \\
\text { Sayısı }\end{array}$} \\
\hline & $\begin{array}{l}\text { Hayvan varlığ } \\
<125 \text { baş için }\end{array}$ & $\begin{array}{l}\text { Hayvan varlığ } \\
125-249 \text { baş için }\end{array}$ & $\begin{array}{l}\text { Hayvan varlığı } \\
>249 \text { baş için }\end{array}$ & \\
\hline Antalya-Manavgat & 24 & 4 & 1 & 29 \\
\hline Antalya - Korkuteli & 6 & 9 & 10 & 25 \\
\hline Antalya - Elmalı & 4 & 6 & 8 & 18 \\
\hline Antalya & 34 & 19 & 19 & 72 \\
\hline
\end{tabular}

\section{Veri analiz metodu}

Küçükbaş hayvan yetiştiriciliğinden elde edilen brüt süt üretim değeri işletmelerin beyan ettikleri toplam süt sağım miktarı ile süt fiyatları çarpılarak hesaplanmıştır. Keçi ve koyun yetiştiriciliğinden elde edilen yan ürün (yün-yapağı, kıl-tiftik, deri, gübre ve Prodüktif Demirbaş Kıymet Artışı-PDKA) üretim değerleri ile süt üretim değeri toplanarak küçükbaş hayvan yetiştiriciliğinden elde edilen brüt üretim değeri hesaplanmıştır (Kıral ve ark, 1999). Üreticilerin beyanına göre işletmelerin büyük bir bölümünde deri geliri elde edilmemekle birlikte, işletmede kesilen hayvanların bir deri üretim değeri olduğu varsayılarak kesilen hayvan sayısı ile deri değeri çarpılarak deri üretim değeri hesaplanmıştır.

İşletmelerde işgücü yapısının incelenmesinde farklı yaş grupları ve farklı cinsiyetteki işgücünün farklı çalışma kudretinde bulunacağı varsayımına dayanılarak işgücü; erkek işgücü birimine (EİB) çevrilmiştir. İşüucü EİB'ne çevrilirken 7-14 yaş arası işgücü 0.50 EİB, 15-49 yaş arası erkek işgücü 1 EİB, $15-49$ yaş arası kadın işgücü 0.75 EİB, 50-64 yaş arası erkek işgücü 0.75, 50-64 yaş arası kadın işgücü ise 0.50 EIB olarak kabul edilmiştir (Erkuş ve ark.1995).Aile iş gücü ücret karşıllğının hesaplanmasında, ilçede benzeri işler için yabancı iş̧̧ilere ödenen ücretler temel alınmıştır. Üreticiler genellikle 365 gün çalıştıklarını beyan etmişler, ancak bu çalışmada yapılan benzer çalışmalardan esinlenilerek yılda çalışılan gün sayısı 250 olarak esas alınmıştır. İşletmede hastalık, eğitim ve askerlik vb. nedenlerle çalışılmayan gün sayıları dikkate alınmamıştır. Aile işgücü ücret karşılığının hesaplanmasında EİB başına günlük ücret incelenen işletmelerde yabancı işçilere ödenen ortalama günlük ücret üzerinden belirlenmiştir (Paksoy, 2007).

Sürü kompozisyonu ise Büyükbaş Hayvan Birimi (BBHB)'ne çevrilerek değerlendirme yapılmıştır. Tekeler ve koçlar için 0.12 , keçiler ve koyunlar için 0.10 , çebiçler için 0.08 , oğlaklar ve kuzular için ise 0.05 katsayısı kullanılmıştır (Erkuş ve ark., 1995).

İncelenen işletmelerde değişken masraflar kaba yem, kesif yem, makine alet değişen masraf, veterinerlik ilaç aşı masrafları, geçici işçilik, çoban masrafı (daimi olmayan çoban ücreti), pazarlama, elektrik, su ve diğer (taşıma, tuz, aydınlatma, ısıtma, dezenfeksiyon vb.), sabit masraflar ise daimi işçilik, bina, makine alet ve hayvan amortismanı, bina, makine alet ve hayvan faizi, bina tamir bakım masrafları, genel idare giderleri şeklinde sınıflandırılmıştır. İncelenen işletmelerde yem masrafı işletme dışından satın alınan yemler ile işletme içinde bitkisel üretim faaliyetleri sonucunda üretilip süt üretim faaliyetinde

${ }^{1}$ Hesaplanan örnek büyüklüğünün \% 20 'si kadar yedek anket doldurulmasına karar verilmiştir. Buna bağlı olarak yapılacak anket sayıs1 145 olarak belirlenmiştir. 
kullanılan yemlerin miktar ve fiyatları çarpılarak elde edilmiştir. Makine alet değişen masrafı, veterinerlik ilaç aşı masrafları, pazarlama, elektrik, su ve diğer değişken giderlerin hesaplanmasında ise üreticiler tarafından fiilen yapılan harcamalar esas alınmıştır (Engindeniz ve ark.,2018; Paksoy,2007 ; Kıral ve ark., 1999).

Bina amortismanı hesaplanırken binaların yapı tarzına bağlı olarak ekonomik ömürleri değişkenlik göstereceğinden, amortisman oranları binaların yapı tarzı dikkate alınarak hesaplamalara dahil edilmiştir. Buna göre amortisman oranları tuğla ve briket binalar için $\% 3$, taş ve beton binalar için $\% 2$, kerpiç ve ahşap binalar için \%4 olarak uygulanmıştır (Engindeniz ve ark., 2018). Ağıl için \%5, kullanılan ambar, yem depoları vb yerler için \%10, makine ve alet için \%10 amortisman oranı kullanılmıştır ( Fidan, 2017).

Amortisman hesaplanırken kullanılan formül aşağıdaki gibidir(Kıral ve ark., 1999);

Amortisman Payı $=(\mathrm{DD}-\mathrm{KD}) /$ Ekonomik Ömür (yıl)

DD: Damızlık Değer

KD: Kasaplık Değer

Hayvan amortismanı hesaplanırken kullanılan formül aşağıdaki gibidir(Kıral ve ark., 1999).

Hayvan Sermayesi Faizi $=[(\mathrm{DD}-\mathrm{KD}) / 2+(\mathrm{KD})] \mathrm{x}$ i

Reel faiz hesaplanırken kullanılan formülaşağıdaki gibidir(Kural ve ark., 1999);

Reel faiz oranı $\mathrm{i}=[(1+\mathrm{r}) /(1+\mathrm{f})]-1$

$\mathrm{i}=$ reel faiz oranı

$\mathrm{r}=$ cari faiz oranı

$\mathrm{f}=$ enflasyon oranı

Faiz masraflarının hesaplanmasında, T.C. Ziraat Bankasınca 2017 yılında üreticilere verilen hayvancılık kredilerine uygulanan (sübvansiyonsuz) carifaiz oranı (\%11) dikkate alınmıştır (Anonim, 2016d). Türkiye'de 2016 yılı ekim - 2017eylül arası tarım ürünleri ÜFE ortalamasına göre enflasyon oranı \% 10,06 olarak hesaplanmıştır (Anonim, 2017). Buna göre hesaplanan reel faiz oranı yıllık \%8,4 olarak hesaplanmış, ortalama 4 aylık süt üretim dönemi dikkate alınarak araştırmada kullanılan reel faiz oranı \%2,8 olarak bulunmuştur.

Birim maliyetlerin hesaplanmasında birleşik maliyet hesaplama yöntemlerinden biri olan nispi satış değerleri yöntemi kullanılmıştır. Bu yönteme göre bir üretim faaliyetinde birden fazla ürün elde edilmesi durumunda üretim masraflarının her bir birleşik ürüne GSÜD'ne yaptıkları katkı oranında dağıtılır. Doğrudan bir üretim faaliyetine yüklenemeyen müşterek masrafların her bir birleşik ürüne dağıtımında ise ödeme kabiliyeti yöntemi uygulanmıştır. Ödeme kabiliyeti yöntemi, en yüksek gelire sahip faaliyet kolunun masraflardan en büyük payı alması gerektiği görüşüne dayanır. GSÜD, Gayrisafi Hasıla (GSH) veya Brüt kar dikkate alınarak dağıtım yapılmaktadır (Kıral ve ark., 1999). Bu çalışmada müşterek masraflar GSÜD dikkate alınarak dağıtılmıştır.

\section{BULGULAR ve TARTIŞMA}

Süt Üretim Faaliyetini Etkileyen Ekonomik Faktörlerin Değerlendirilmesi

Dünya'da 2016 yılında FAO veri tabanından elde edilen verilere göre 15.262 .116 ton keçi sütü, 10.366.980 ton koyun sütü üretimi gerçekleşmiştir. Sağılan keçi sayısı 2016 yılı için 202.690.015 iken ve sağılan koyun sayısı 249.522.556 dur. Dünya toplam çiğ süt üretimi içerisinde keçi sütünün payı yaklaşık $\% 2$ iken, koyun sütünün payı ise yaklaşık \%1,2 dir. Dünyada süt üretimi içerisinde en büyük payı yaklaşık $\% 82$ ile inek sütü, yaklaşık \%14 lük payı ile bizon (buffalo) sütü almaktadır. Deve sütü ise $\% 0,3$ gibi bir pay ile en az paya sahiptir (Anonim, 2016c). Keçi sütünün sağlık açısından önemi sebebi ile son yıllarda keçi sütüne olan talep hem gelişmekte olan ülkelerde, hem de gelişmiş ülkelerde artmaktadır (Ateş ve ark., 2014).

Türkiye'de koyun ve keçi yetiştiriciliğinde $80^{\prime}$ lı yıllardan 2009 yılına kadar ciddi boyutlarda küçülme yaşanmıştır. Bunun başlıca nedenleri her iki üretim dalının da geleneksel, düşük girdi ve düşük çıktı yapısında, düşük verimli ırkların hâkim olduğu küçük işletmelerden oluşması ve bununla birlikte küçükbaş hayvancılık desteklemelerinin hayvancılık desteklemeleri içinde aldıkları payın önemli derecede düşük olmasıdır. $\mathrm{Bu}$ anlamda koyun ve keçi yetiştiriciliğinde sürdürülebilir bir yapr gözlenmemektedir. Ayrıca Türkiye'de koyun ve keçi yetiştiriciliğindeki örgütlenme yapısı çok düşük düzeydedir (Gürsoy 2009). Uygulanan destekleme politikalarının hayvancilıkta istenen hedeflere ulaşılamaması ve sorunların giderilmesine yönelik olarak 2000 yılında Hayvancılığın desteklenmesi ve Geliştirilmesi projesi kapsamda 2000/467 sayılı "Hayvancılığın Desteklenmesi Kararnamesi" yürürlüğe girmiştir. $\mathrm{Bu}$ kararname ile birlikte destekleme kalemlerinin sayısı artmış, 2004 yılında toplam tarımsal desteklemeler içerisinde hayvancılık desteklemelerinin payı \%4 iken, 2009 yılında \%22'ye çıkmıştır (Demir ve Yavuz, 2010). Mevcut veriler, Türkiye'de küçükbaş hayvancılığın destekleme kapsamına alınması ile birlikte küçükbaş hayvan yetiştiriciliğinde bir canlanma yaşandığını göstermektedir. Koyun ve keçi başına verilen destekler, süt desteği ve diğer destekler ile birlikte bu sektörde yatırımlar artmış ve küçükbaş hayvan varlığı artı̧̧ göstermiştir. Buna bağlı olarak aynı sektörden elde edilen süt ve et üretiminde de artış yaşanmıştır. 
Türkiye'de sağılan koyun (yerli+ merinos) sayısı 2009 yılında yaklaşık 9 milyon iken, 2015 yılında yaklaşık 15,3 milyona, keçi(kıl keçisi+ tiftik keçisi) sayısı ise aynı dönemde yaklaşık 2 milyondan, 4,5 milyona çıkmıştır. Koyun sütü üretimi 2009 yılında yaklaşık 735.000 tondan, 2015 yllında 1,1 milyon tona yükselmiş, keçi sütü üretimi ise aynı dönemde yaklaşık 192.000 tondan 480.000 tona ulaşmıştır (Anonim, 2015).
Şekil 1 'de 2015 yılı için Antalya ilinde desteklenen damızlık koyun- keçi yetiştiricilerinin ilçelere göre dağ $\breve{l l}_{1}$ ı verilmektedir. Manavgat, Korkuteli ve Elmalı ilçelerindeki yetiştirici sayısı Antalya ili toplam küçükbaş hayvan yetiştirici sayısının \%49,4'üne denk gelmektedir.

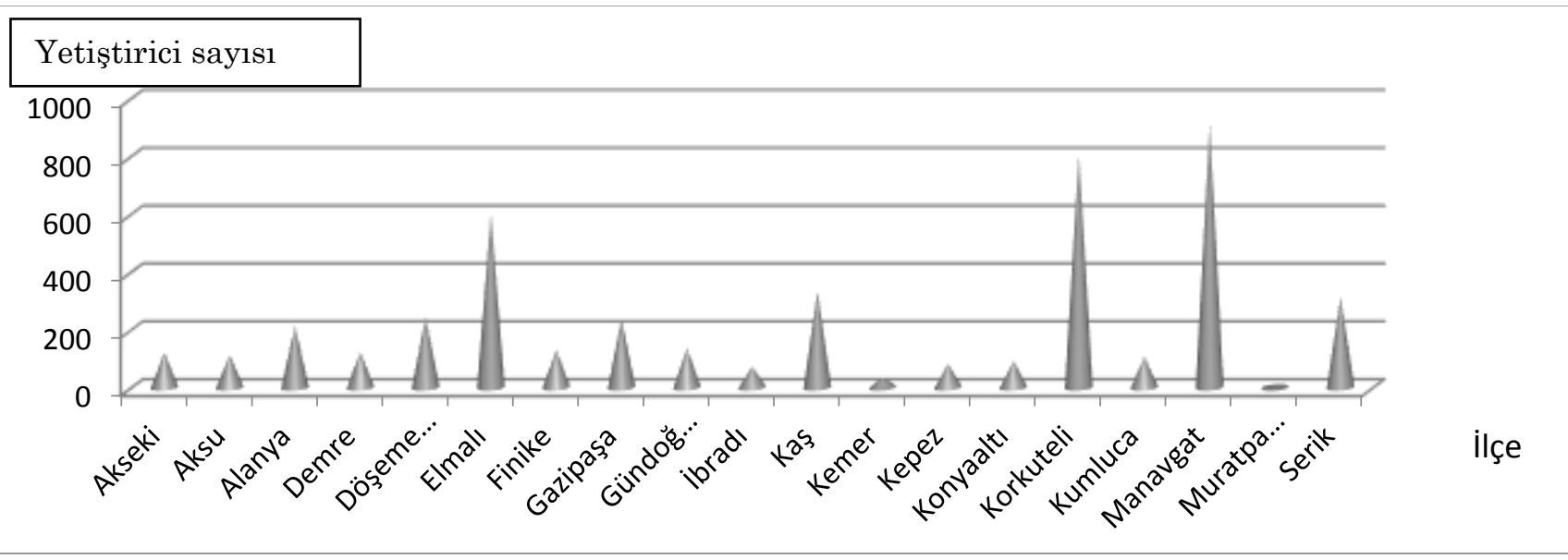

Şekil 1. Antalya'da ilçelere göre desteklenen küçükbaş hayvan yetiştiricisi sayısı (2015)

Manavgat, Korkuteli ve Elmalı ilçelerindeki anaç koyun keçi toplamı Antalya ili toplam anaç koyun keçi sayısının \%52,72 sine denk gelmektedir. 2015 yılında Antalya ili için anaç koyun keçi başına verilen desteklemeler 2015 yılı için toplam 13,1 milyon TL olup Manavgat, Korkuteli ve Elmalı ilçelerinde faaliyet gösteren yetiştiricilere yapılan ödemeler yaklaşı 6,9 milyon TL'yi bulmaktadır.

Şekil 2'de incelenen işletmelerin yetiştirilen küçükbaş hayvan cinsine göre dağılımı verilmiştir. Buna göre incelenen 72 işletmeden 35'ü koyun yetiştiriciliği, 19'u keçi yetiştiriciliği, 18'i ise hem koyun hem de keçi yetiştiriciliği yapmaktadır.

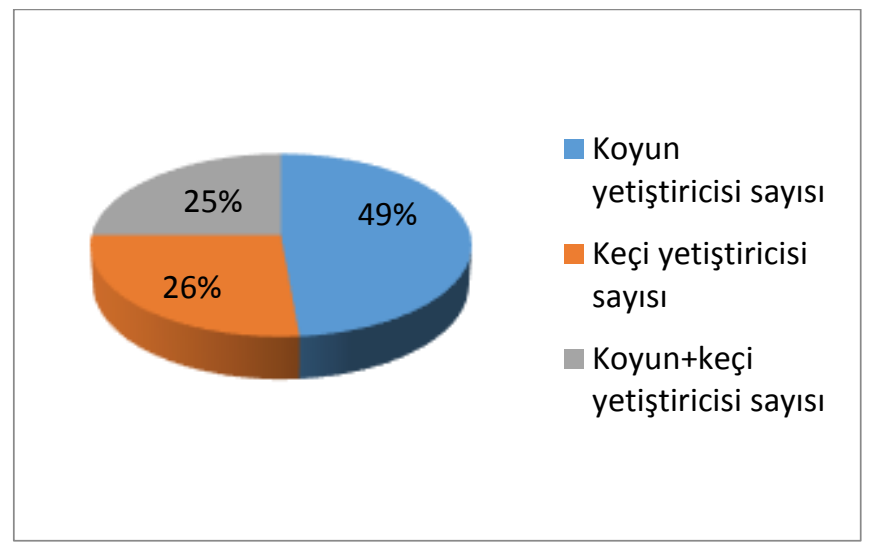

Şekil 2. İncelenen işletmelerin yetiştirdikleri küçükbaş hayvan cinsine göre dağılımı

\section{İşletmelerde Nüfus ve İşgücü Yapısı}

Üretimin daha çok ekstansif yöntemlerle gerçekleştirildiği küçükbaş hayvancılık işletmeleri aile işletmeleri şeklinde faaliyet göstermektedir (Ateş ve ark., 2014).Küçükbaş hayvancılık işletmelerinde işgücünün büyük bir bölümü aile bireylerinden oluşmaktadır. Aile bireyleri evlendiklerinde veya aile büyükleri vefat ettiğinde genellikle bu mesleği devam ettirmekte ve küçükbaş hayvancılık üretimi nesilden nesle bu yolla aktarılmaktadır.

Çizelge 3'de işletmelerin büyüklük gruplarına göre nüfus ve işgücü yapısı verilmektedir. Araştırmaya dâhil olan işletmelerde işletme büyüklük gruplarına göre nüfus ve işgücü incelendiğinde 125 küçükbaş hayvandan daha az hayvana sahip işletmelerde işletme başına ortalama nüfus 4 kişi, işletme başına çalışan aile bireyi ortalama 2.52 kişi, işletme başına ortalama işgücü 1.88 EİB olarak bulunmuştur. Yetiştirilen anaç koyun ve keçi sayısının 125 ile 249

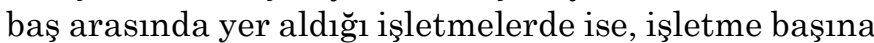
nüfus ortalama 5.15 , işletme başına çalışan aile bireyi sayısı 3.15, işletme başına işgücü ise 2.5 EİB olarak bulunmuştur. 250 baş ve üzeri anaç koyun ve keçi sahibi işletmelerde ise işletme başına nüfus ortalama 5.94, işletme başına çalışan aile bireyi sayısı 4.31, işletme başına işgücü ise 3.6 EİB olarak bulunmuştur. İşletme büyüklüğü arttıkça işletme başına düşen ortalama nüfus ve işgücü artmaktadır. Araştırmaya dâhil olan küçük ölçekli işletmelerde yabancı iş̧̧i çalıştırılmazken, işletme büyüklüğü arttıkça yabancı işçi çalıştırma eğiliminin arttığı gözlemlenmiştir. 
Çizelge 3. İncelenen işletmelerde nüfus ve işgücü

\begin{tabular}{|c|c|c|c|c|}
\hline & \multicolumn{3}{|c|}{ İșletme Büyüklük Grupları } & \multirow{2}{*}{ Toplam } \\
\hline & $<125$ baş & $125-249$ baş & $>249$ baş & \\
\hline İşletme başına ortalama nüfus & 4 & 5,15 & 5,94 & 4,81 \\
\hline İşletme başına ortalama çalışan aile bireyi & 2,52 & 3,15 & 4,31 & 3,16 \\
\hline İşletme başına ortalama Aİ̈̈K (TL/yıl) & $23.621,3$ & $31.250,0$ & $45.065,8$ & $31.293,4$ \\
\hline İşletme başına ortalama Yİ̈̈K (TL/yıl) & 0 & $3,928.94$ & $6,297.13$ & $2,698.494$ \\
\hline İşletme başına EIBB & 1,88 & 2,5 & 3,6 & 2,5 \\
\hline
\end{tabular}

Ai்ÜK: Aile işgücü ücret karşılığı, EİB: Erkek işgücü birimi, YİÜK: Yabancı işgücü ücret karşılığı

\section{İşletmelerde Süt Verimi}

Sürü büyüklüğü ve sağllan hayvan başına süt verimlerinin işletme büyüklük grupları ve işletme türüne göre dağılımı Çizelge 4'te verilmektedir. Sağılan hayvan başına süt verimi keçi işletmelerinde $0,35 \mathrm{~kg} /$ gün, koyun işletmelerinde $0,23 \mathrm{~kg} / \mathrm{gün}$ olarak bulunmuştur. Çanakkale, İzmir ve Balıkesir'de gerçekleştirilen bir araştırmada süt veriminin 1.35 ile
$1.95 \mathrm{~kg} /$ gün arasında değiştiği görülmektedir (Engindeniz ve ark., 2018). Bu değerlerle karşılaştırıldığında Antalya'da keçi sütü veriminin çok düşük olduğu gözlenmektedir. Ortalama süt fiyatları, toplam sütten elde edilen GSÜD, toplam süt sağım miktarına bölünerek elde edilmiştir. $\mathrm{Bu}$ verilere göre incelenen işletmelerde $1 \mathrm{~kg}$ koyun sütünün fiyatı keçi sütüne göre daha yüksek bulunmuştur

Çizelge 4. İncelenen işletmelerde süt verimi

\begin{tabular}{lllllll}
\hline & \multicolumn{3}{l}{ İşletme büyüklük grupları } & \multicolumn{3}{l}{ İşletme Türü } \\
\cline { 2 - 7 } & $<125$ baş & $125-249$ baş & $>249$ baş & Koyun & Keçi & Küçükbaş̧ \\
\hline İşletme başına sürü büyüklüğ̈̈ (BBHB) & 9.08 & 22.46 & 40.9 & 12.79 & 22.55 & 21.01 \\
Ortalama Laktasyon süresi (gün/yıl) & 80.00 & 89.21 & 69.12 & 90.15 & 71.70 & 79.03 \\
Hayvan başın süt verimi (kg/gün) & 0.26 & 0.31 & 0.30 & 0.23 & 0.35 & 0.29 \\
Ortalama Süt Fiyatı (TL/kg) & 4.69 & 4.58 & 3.94 & 4.74 & 3.93 & 4.32 \\
\hline
\end{tabular}

\section{İşletmelerde Sütün Pazarlanma Şekli}

İncelenen işletmelerde Batı Akdeniz bölgesinde keçi ve koyun sütünün genellikle müşteriye sağıldıktan sonra satıldığı ve keçi ve koyun sütünün toplanması için toplama merkezlerinin bulunmadığı ve soğuk zincir uygulamasının bölgede gelişmediği görülmüsşür.

Sütün çiğ süt olarak pazara arzının diğer süt ürünlerine göre görece olarak daha düşük kaldığ gözlenmektedir. Çiğ süt; peynir, tereyağı, çiğ süt ve yoğurt olarak değerlendirilmekte ve direkt müşteriye, semt pazarina veya toptancıya pazarlanmaktadır. Antalya ilinde incelenen işletmelerde sağılan toplam sütün yaklaşı \%54 'ü peynir, \%20 'si tereyağı , \%14'ü çiğ süt, \%11,5’u ise yoğurt olarak değerlendirilmektedir. Sağılan toplam keçi sütünün yaklaşık \%62 'sinin peynir, \%25 'inin tereyağ 1 , $\% 6$ 'sının çĭ̆ süt, \%8'inin ise yoğurt olarak değerlendirildiği görülmüştür. İncelenen işletmelerde sağılan toplam koyun sütünün ise yaklaşık \%47 'si peynir, \%16'sı tereyağı , \%22'si çiğ süt, \%14,5’u ise yoğurt olarak değerlendirilmektedir.

\section{İşletmelerde Sütün Gayrisafi Üretim Değeri}

İncelenen işletmelerde gayrisafi süt üretim değerinin ana ürün (süt) ve yan ürünlerden (kıl-yün, gübre, deri ve prodüktif demirbaş kıymet artışı (PDKA)) elde edilen üretim değerlerine dağılımı Çizelge 5'de verilmektedir. Gayrisafi üretim değeri içinde en büyük payı PDKA almaktadır. Süt üretim değerinin GSÜD içerisindeki payı ise işletme büyüklük gruplarına göre farklılık göstermektedir. Birinci grup işletmelerde sütün gayrisafi üretim değerinin toplam içindeki payı \%9.6 iken, 2. grup işletmelerde \%14.3, 3. grup işletmelerde ise ortalama \%13.1'dir. Koyun ve keçi yetiştiriciliğinde süt üretim değerinin GSÜD içindeki payı sırasıla \%11,9 ve \% 13,3, tüm işletmeler ortalamasında ise $\% 12,5$ olarak bulunmuştur.

\section{İşletmelerde Değişen ve Sabit Masraflar}

Antalya'da araştırmaya dâhil olan işletmelerin değişken ve sabit masrafları Çizelge 6'da verilmektedir. Masraf toplamının yaklaşık \%49,6'sı değişken masraflardan, \% 50,3'sı ise sabit masraflardan oluşmaktadır.

Yem masrafları \%40'lık payı ile en büyük masraf kalemini oluşturmaktadır. Daimi yabancı iş̧̧ilik de sabit masraflar altında değerlendirilmiştir. Daimi işçilik masrafları altında yer alan AÏ̈̈K ise üretim masraflarının yaklaşık \%33,5’ini oluşturmaktadır. İşletme büyüklük gruplarına göre incelendiğinde yem masraflarının toplam üretim masrafları içindeki payı işletme ölçeği büyüdükçe artarken, aile işgücü ücret karşılı̆̆ının toplam masraflar içindeki payı azalmaktadır. 
Çizelge 5. İncelenen işletmelerde işletme başına ortalama gayrisafi üretim değeri

\begin{tabular}{|c|c|c|c|c|c|c|c|}
\hline & \multicolumn{3}{|c|}{ İşletme büyüklük grupları } & \multicolumn{3}{|c|}{ İşletme Türü } \\
\hline & & $<125$ baş & $125-249$ baş & $>249$ baş & Koyun & Keçi & Küçükbaş \\
\hline \multicolumn{2}{|c|}{ Toplam Süt Üretimi (kg) } & 412,17 & 1332,15 & 1760,92 & 707,43 & 1153,86 & 1003,09 \\
\hline \multirow{7}{*}{$\begin{array}{l}\text { Gayrisafi } \\
\text { Üretim } \\
\text { Değeri(TL/yl) }\end{array}$} & Süt & 1933,25 & 6098,24 & 6943,17 & 3351,41 & 4536,68 & 4338,19 \\
\hline & Kıl-yün & 66,00 & 107,68 & 93,28 & 98,52 & 36,54 & 84,42 \\
\hline & Gübre & 634,74 & 109,39 & 118,56 & 634,13 & 103,51 & 899,50 \\
\hline & Deri & 1,23 & 3,29 & 4,17 & 0,79 & 4,46 & 2,53 \\
\hline & PDKA & 17589,20 & 35429,27 & 44855,28 & 24047,13 & 28496,69 & 29322,23 \\
\hline & Toplam & 20224,41 & 42732,39 & 53081,44 & 28131,97 & 34109,45 & 34646,87 \\
\hline & Sütün Payı \% & 9,6 & 14,3 & 13,1 & 11,9 & 13,3 & 12,5 \\
\hline
\end{tabular}

PDKA: Prodüktif Demirbaş Kıymet Artışı

Cizelge 6. İşletmelerde toplam yıllık değişen ve sabit masrafların toplam masraftaki payı (\%)

\begin{tabular}{|c|c|c|c|c|c|c|}
\hline & \multicolumn{3}{|c|}{ İsletme Grupları } & \multirow{2}{*}{ Koyun } & \multirow{2}{*}{ Keçi } & \multirow{2}{*}{ Küçükbaş } \\
\hline & $<125$ baş & $125-249$ baş & $>249$ baş & & & \\
\hline $\begin{array}{l}\text { I. Değişken masraflar } \\
(1+2+3+4+5+6+7+8)\end{array}$ & 45,19 & 48,96 & 53,43 & 48,19 & 51,66 & 49,66 \\
\hline 1.Yem masrafları & 37,23 & 39,42 & 43,23 & 39,93 & 40,88 & 40,33 \\
\hline 2. Makine alet değişen masrafı & 0,00 & 0,00 & 0,01 & 0,00 & 0,01 & 0,01 \\
\hline 3. Veterinerlik -ilaç masrafi & 3,37 & 3,64 & 3,81 & 2,86 & 4,66 & 3,63 \\
\hline 4. Geçici işçilik masrafi & 0,00 & 1,25 & 0,67 & 0,67 & 0,55 & 0,62 \\
\hline 5. Pazarlama masrafi & 0,17 & 0,17 & 0,34 & 0,18 & 0,32 & 0,24 \\
\hline 6. Su masrafi & 0,83 & 0,73 & 1,44 & 0,75 & 1,48 & 1,06 \\
\hline 7. Elektrik masrafi & 1,06 & 0,81 & 1,43 & 1,07 & 1,26 & 1,15 \\
\hline 8. Diğer & 2,52 & 2,93 & 2,52 & 2,72 & 2,51 & 2,63 \\
\hline $\begin{array}{l}\text { II. Sabit masraflar } \\
(9+10+11+12+13+14+15+16+17)\end{array}$ & 54,81 & 51,04 & 46,57 & 51,81 & 48,34 & 50,34 \\
\hline 9. Daimi işçilik masrafi & 35,93 & 33,46 & 31,77 & 35,23 & 31,20 & 33,52 \\
\hline Daimi işgücü, çoban masrafi & 0,00 & 2,63 & 3,31 & 1,85 & 2,43 & 2,09 \\
\hline Aile işgücü ücret karşılliğ & 35,93 & 30,84 & 28,46 & 33,38 & 28,77 & 31,43 \\
\hline 10. Bina sermayesi amortismanı & 6,72 & 3,90 & 1,24 & 4,56 & 2,43 & 3,66 \\
\hline 11. Bina sermayesi faizi & 2,73 & 1,49 & 0,65 & 1,80 & 1,15 & 1,52 \\
\hline 12. Makine alet amortismanı & 0,08 & 0,06 & 0,07 & 0,06 & 0,08 & 0,07 \\
\hline 13. Makine alet faizi & 0,04 & 0,02 & 0,03 & 0,03 & 0,04 & 0,03 \\
\hline 14. Hayvan sermayesi amortism. & 3,01 & 5,18 & 5,91 & 4,03 & 5,87 & 4,81 \\
\hline 15. Hayvan faizi & 2,20 & 3,79 & 4,33 & 2,95 & 4,30 & 3,52 \\
\hline 16. Bina tamir bakım masrafı & 2,74 & 1,66 & 0,98 & 1,71 & 1,71 & 1,71 \\
\hline 17. Genel idari giderler & 1,36 & 1,47 & 1,60 & 1,45 & 1,55 & 1,49 \\
\hline III. ÜRETIMM MASRAFLARI (I+II) & 100,00 & 100,00 & 100,00 & 100,00 & 100,00 & 100,00 \\
\hline
\end{tabular}

\section{İşletmelerde Yem Masraflarının Dağılımı}

İncelenen işletmelerde toplam masraflar içerisinde en yüksek masraf kalemini yem masrafları oluşturmaktadır. $\mathrm{Bu}$ nedenle işletmelerin yem masrafları ve yem masraflarının dağılımı ayrıca incelenmiştir. Şekil 3'de Antalya ili için işletme büyüklük gruplarına göre kaba ve kesif yem masraflarının dağılımı gösterilmektedir. Antalya ilinde işletme başına ortalama yem masraflarının yaklaşık \%40'ını kaba yem (saman, yonca-fiğ kuru otları, silaj vb), yaklaşık \%60'inı ise kesif yem (süt yemi, besi yemi, arpa, buğday vb.) masrafları oluşturmaktadır. İşletmelerin yem masrafları işletmeler tarafından satın alınan yem ile işletmelerin yem üretim değerlerinin toplamından oluşmaktadır.

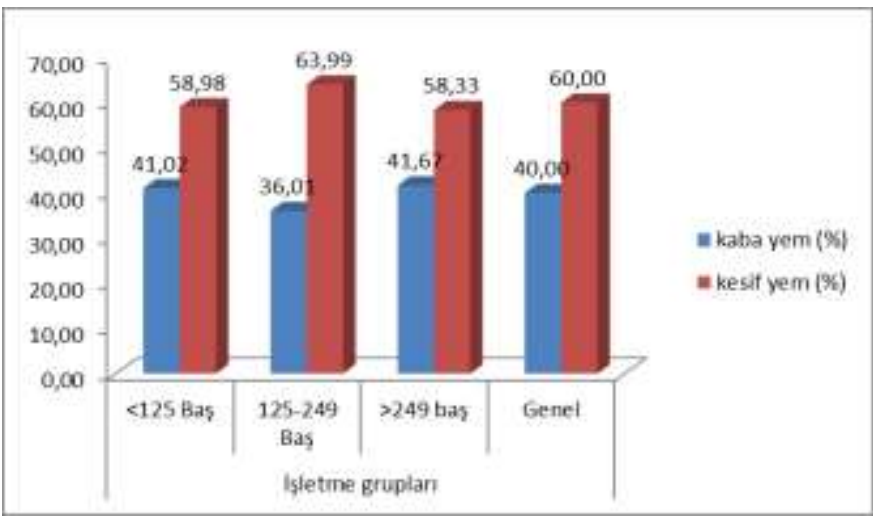

Şekil 3. İşletme Büyüklük Gruplarına göre kaba yem kesif yem masraflarının dağılımı 
Antalya'da araştırmaya dâhil olan işletmelerde toplam yem üretim değeri toplam yem masrafının yaklaşık \%16,5'ini oluşturmaktadır. Ancak incelenen işletmelerde yem bitkileri üretimi yapan 41 işletmeden sadece 2 tanesi yem bitkileri desteğinden yararlanmıştır. İşletmelerin yem bitkileri desteğinden yararlanma oranlarının bu kadar düşük olması incelenmesi gereken ayrı bir konudur. Bununla birlikte desteklemelerden yararlanma oranının arttırılması, yem bitkileri üretimi gerçekleştiren işletmelerde yem masrafı kaleminin azaltılmasında etkili olabilir.

\section{İşletmelerin Süt Üretiminde Karlılık Düzeyleri}

Küçükbaş hayvan yetiştiriciliğinin ve süt üretimi faaliyetinin ekonomik olarak sürdürülebilir olması işletmelerin faaliyet sonuçlarının kar ile sonuçlanmasına bağlıdır.

Çizelge 7 incelenen işletmelerde işletme büyüklük grupları ve koyun keçi yetiştiriciliği sınıflamasına göre birim süt geliri, birim süt maliyeti, birim brüt süt karı ve birim net süt karı verilmektedir. Süt gelirinin işletme büyüklüğü arttıkça azalması dikkat çekici bir göstergedir. En düşük birim değişken maliyetler ikinci işletme grubunda gözlemlenirken, birim sabit maliyetler işletme ölçeği arttıkça azalmaktadır. Antalya ili için araştırmanın yapıldı ̆̆ dönemde işletme büyüklük gruplarına göre incelendiğinde birim brüt süt karının pozitif olduğu görülürken, birim net süt karının ise negatif olduğu bulunmuştur. Koyun yetiştiriciliği süt üretim masrafları, keçi yetiştiriciliğine göre daha yüksek bulunmuştur. İşletmeler büyüklük gruplarına göre incelendiğinde birim brüt süt karı pozitif bulunmuştur. Bu değerlere göre işletmeler değişken masraflarını ve sabit masraflarının bir bölümünü karşllayabilecek geliri elde etmektedir. En yüksek brüt karın ikinci grup işletmeler tarafından elde edilmesi ise dikkat çekici bir göstergedir. İncelenen işletmeler net kar açısından, işletme büyüklük gruplarına göre incelendiğinde, üreticilerin bir kg süt üretiminde zarar ettikleri tespit edilmiştir.

Çizelge 7. İncelenen işletmelerde birim süt geliri, birim süt maliyeti, birim brüt süt karı ve birim net süt karı

\begin{tabular}{lrrrrrr}
\hline & \multicolumn{3}{c}{ İşletme grupları } & \multicolumn{3}{c}{ İşletme Türü } \\
\cline { 2 - 7 } & $<125$ baş & $125-249$ baş & $>249$ baş & Koyun & Keçi & Küçükbaş \\
\hline Toplam Süt Üretimi (kg) & 28.440 & 54.618 & 63.393 & 71.450 & 75.001 & 14.6451 \\
\hline GSÜD içinde Sütün Payı (\%) & 9,6 & 14,3 & 13,1 & 11,9 & 13,3 & 12,5 \\
\cline { 2 - 7 } Üretim masrafları (TL) & 2.235 .261 & 1.925 .383 & 3.008 .886 & 4.130 .909 & 3.038 .621 & 7.169 .529 \\
Süte düşen üretim masrafı (TL) & 213.668 & 274.767 & 393.569 & 492.122 & 404.147 & 897.709 \\
Birim süt geliri (TL/kg) & 4,69 & 4,58 & 3,94 & 4,74 & 3,93 & 4,32 \\
Birim değişken masraf (TL/kg) & 3,40 & 2,46 & 3,32 & 3,32 & 2,78 & 3,04 \\
Brüt Kar (TL/kg) & 1,30 & 2,11 & 0,63 & 1,42 & 1,15 & 1,28 \\
Birim sabit masraf & 4,12 & 2,57 & 2,89 & 3,57 & 2,60 & 3,09 \\
Kar (BK-SM) & $-2,82$ & $-0,45$ & $-2,27$ & $-2,15$ & $-1,46$ & $-1,80$ \\
\hline
\end{tabular}

\section{SONUÇ ve ÖNERILER}

Türkiye'de küçükbaş hayvancılık yetiştiriciliği daha çok ekstansif (geleneksel) yöntemlerle yapılmaktadır. Özellikle keçi yetiştiriciliği Antalya'da yaylacılık tarzında üretim şeklinde ve genellikle göçer olarak uygulanmaktadır. Küçükbaş hayvancılık yetiştiriciliğinin gelecek nesillere taşınması yaylacılık kültürünün devam ettirilmesine bağlıdır (Ateş ve ark. 2016). Ancak mera ve orman kisitlılığ yetiştiricilerin karşılaştığı önemli sorunlardan biri olarak karşımıza çıkmaktadır. Ayrıca dağlardaki kurtlar sürü için önemli bir tehdit oluşturmaktadır. Otlatmanın ormana verdiği zararı en aza indirgeyecek şekilde ve keçi ve koyun yetiştiricilerinin de zararını azaltacak politikaların geliştirilmesi gereklidir. $\mathrm{Bu}$ sorunun önüne geçilebilmesi için getirilen önerilerden bir tanesi de "gençlesstirme alanları ile erozyon baskısının görüldüğü alanlar dışında kalan, ağaçları olgunlaşmış ormanların geç ilkbahar ve sonbahar dönemlerinde denetimli olarak otlatmaya" açılmasıdır (Paksoy, 2007).

Antalya ili için incelenen işletmelerde, en büyük masraf kalemini yem masrafları oluşturmaktadır. Üreticilerin temel problemlerinden bir tanesi yem fiyatlarının çok yüksek olmasıdır. Mera ve otlak alanlarının orman bakanllğ kapatılması ise üreticilerin daha fazla yem kullanmaları ihtiyacını doğurmaktadır. Antalya'da araştırmaya dâhil olan işletmelerde toplam yem üretim değeri toplam yem masrafının yaklaşık \%16,5’ini oluşturmaktadır. Ancak incelenen işletmelerde yem bitkileri üretimi yapan 41 işletmeden sadece 2 tanesi yem bitkileri desteğinden yararlanmıştır. İşletmelerin yem bitkileri desteğinden yararlanma oranının düşük olması da bu masraf kaleminin azaltılmasına yönelik desteklemelerin uygulamada karşılık bulmadığını göstermektedir. Yetiştiricilerin bakanlık tarafindan verilen küçükbaş hayvancılık desteklemeleri ve desteklerden yararlanma koşulları hakkında bilgilendirilmesi yolu 
ile daha fazla yetiştiricinin desteklemelerden faydalanması sağlanabilir. Bununla birlikte yem bitkileri desteklemelerinden yararlanma oranının arttırılması, yem bitkileri üretimi gerçekleştiren işletmelerde yem masrafı kaleminin azaltılmasında etkili olabilir. Bir çalışmada; hayvancılık desteklemelerinden faydalanmada bölgeler arasında var olan farklılıklar ve çiftçilerin desteklere olan yaklaşımlarının farklılığı göz önüne alınarak bölgesel farklılıkları dikkate alan destekleme politikalarının kurgulanması gerektiği vurgulanmıştır (Demir ve Yavuz,2010).

Destekleme ve teşviklerin yetersiz olması küçükbaş hayvancilık süt üretimi faaliyetinin sürdürülebilirliğinin önündeki engellerden bir diğeridir.(Ateş ve ark, 2014). Destekleme mekanizmalarının etkinliğinin artırılması için yetiştiricilerin bu konuda bilinçlendirilerek desteklemelerden daha fazla yararlanmaları teşvik edilmelidir. Yem üretimi ve işletmelerin yem bitkileri desteklerinden yararlanma eğiliminin artması, yem maliyetlerini azaltıcı etki gösterebilir. $\mathrm{Bu}$ alanda verilen bir başka destekleme kalemi de süt teşvikidir. Süt teşvikinden yararlanmak için işletmelerin üretmiş olduğu çiğ sütü 17.12.2011 tarihli ve 28145 sayılı resmi gazetede yayınlanan "Gıda İşletmelerinin kayıt ve onay işlemlerine dair Yönetmelik" kapsamındaki süt işleme tesislerine satması, bu kararın 12. Maddesinde belirtilen ve ulusal düzeyde üst örgütlemesini tamamlamış bir hayvancılık örgütüne üye olması gerekmektedir(Engindeniz ve ark., 2018).Süt teşvik priminin arttırılması ve üreticilerin sütlerini süt toplama merkezlerine satmaya teşvik edilmesi ile süt primin etkinliği artırılabilir (Sayın ve ark. 2007).Ancak Antalya'da Küçükbaş hayvancılık süt üretim faaliyetine yönelik soğuk zincir uygulaması ve süt toplama merkezlerinin olmayışı, bununla birlikte yetiştiriciler arasında örgütlenmenin zayıf oluşu süt teşvikinden yaralanma olanağını bu bölgede yetiştiriciler açısından olanaksız kılmaktadır. Yetiştiricilerin söz sahibi olduğu kooperatiflerin kurulması, yetiştiricilerin pazarlık gücünün artmasını ve küçükbaş hayvan yetiştiriciliğinden elde edilen katma değerin çok büyük ölçüde üreticiye dönmesini sağlayacaktır (Kaymakçı, Engindeniz 2010).

Ekonomik anlamda küçükbaş hayvancılıkta sürdürülebilirliğin sağlanması masrafların düşürülmesi veya süt gelirinin arttırılmasına bağlıdır. Antalya ili için araştırmanın yapıldığı dönemde işletme büyüklük gruplarına göre ve koyun ve keçi sütü üretiminde, birim brüt süt karının pozitif olduğu görülürken, birim net süt karı ise negatif bulunmuştur. Bu göstergeler küçükbaş hayvancılık süt üretimi faaliyetinin ekonomik olarak sürdürülebilirliği açısından tehlike sinyalleri vermektedir. Antalya'da küçükbaş hayvancılık süt üretiminin ekonomik olarak sürdürülebilirliğini sağlamak için süt üretimi gelirini artıracak ve yem masraflarını azaltacak önlemlerin alınması ve yetiştiricilerin daha fazla destekleme kaleminden yararlanabilmesi için gerekli düzenlemelerin yapılması gerekmektedir.

\section{TEŞEKKÜR}

Bu çalışmada; Akdeniz Üniversitesi Bilimsel Araştırma Projeleri Koordinasyon Merkezi(BAP)tarafindan desteklenen FDK-2017-2599 no’lu "Damızlık Küçükbaş Hayvancılıkta Destekleme Politikalarının İşletmelere Etkisi Batı Akdeniz Bölgesi Politika Analizi Matrisi Yaklaşımı " başlıklı Doktora Tez Projesi kapsamında gerçekleştirilen anket çalışması ile elde edilen veriler kullanılmıştır. Bu araştırmaya FDK-2017-2599 no'lu proje çerçevesinde destek sağlayan Akdeniz Üniversitesi Bilimsel Araştırma Projeleri Koordinasyon Merkezi (BAP)ne ve anket sorularına sabırla cevap veren üreticilere teşekkür ederiz.

\section{KAYNAKLAR}

Aracı H, Yüksel F 2016. Sürdürülebilirlik performansının ölçülmesi: Bist sürdürülebilirlik endeksindeki işletmelerin Sürdürülebilir katma değerinin hesaplanması. Uluslararası Yönetim İktisat ve İşletme Dergisi, 30:786-801.

Anonim 1987.WCED Report. OurCommonFuture (1987),WCED Report. http://www.un-documents .net/our-common-future.pdf, (Erişim tarihi: 25.08.2018)

Anonim, 2010. Dünya ve Türkiye Süt Endüstrisi Raporu, Ambalajlı Süt ve Süt Ürünleri Sanayicileri Derneği (ASÜD).

Anonim 2014a. Anaç Koyun- Keçi Desteklemeleri. Gıda, Tarım ve Hayvancılık Bakanlığı, Antalya Tarım İl Müdürlüğü.

Anonim 2014b. Anaç Koyun- Keçi Desteklemeleri. Burdur Damızlık Koyun-Keçi Yetiştiricileri Birliği.

Anonim. 2014c. Anaç Koyun- Keçi Desteklemeleri. Isparta Damızlık Koyun-Keçi Yetiştiricileri Birliği.

Anonim 2015. TÜİK Hayvancilık İstatistikleri. http://tuikapp.tuik.gov.tr/hayvancilikapp/hayvanci lik.zul, (Erişim tarihi: 05.03.2015)

Anonim. 2016a. Anaç Koyun- Keçi Desteklemeleri. Antalya Damızlık Koyun-Keçi Yetiştiricileri Birliği.

Anonim. 2016b. Anaç Koyun- Keçi Desteklemeleri. Antalya Damızlık Koyun-Keçi Yetiştiricileri Birliği.

Anonim. 2016c. Live Animals Statistics. http://faostat.fao.org, (Erişim tarihi: 05.07.2018).

Anonim. 2016d. http://www.furkanlardanismanlik. com/index.php/destekler/suebvansiyonlu-krediler /2726-2017-yili-s\%C3\%BCbvansiyonlu-tarimsalkredi-faiz-oranlari.html (Erişim tarihi: 05.04.2018).

Anonim 2017. TÜİK Tarım Ürünleri Üretici Fiyat Endeksi ve değişim oranları İstatistikleri. 
http://www.tuik.gov.tr/UstMenu.do?metod=temelis t ( Erişim tarihi: 05.04.2018).

Ateş G, Yelboğa MNM, Sayın C 2014.Antalya ilinde Kıl Keçisi Yetiştiriciliğinin mevcut durumu, Sorunlar ve Çözüm Önerileri. XI. Ulusal Tarım Ekonomisi Kongresi 3-5 Eylül 2014, Samsun

Bozoğlu M, Ceyhan V, Cinemre A, 2001. Tonya ilçesinde süt işletmelerinin ekonomik yapısı ve karşılaştıkları riskler: risk ölçümü uygun risk yönetim stratejileri. Türkiye Ziraat Odaları Birliği Yayınları, yayın no: 228, Ankara.

Demir N, Yavuz F 2010. Hayvancılık Destekleme Politikalarına Çiftçilerin Yaklaşımlarının Bölgelerarası Karşılaştırmalı Analizi. Atatürk Üniversitesi Ziraat Fakültesi Dergisi, 41 (2):113121.

Doğan N, Kızıloğlu S, Bayram B, 2013. Organik ve konvansiyonel süt üretimi yapan işletmelerde üretim maliyetlerinin karşılaştırılması. V. Organik Tarım Sempozyumu, 25-27 Eylül 2013, Samsun.

Engindeniz S, Aktürk D, A. Ferhan SA, Koşum N, Taşkın T, Kesenkaş H, Uzmay A, Gökmen M, Öztürk G 2018. İzmir, Çanakkale ve Balıkesir Illerinde Keçi Sütü Maliyetinin Saptanması Üzerine Bir Araştırma. Ege Univ. Ziraat Fak. Dergisi, 55 (1):27-36.

Erkuş A, Bülbül M, Kıral T, Açıl AF, Demirci R 1995. Tarım ekonomisi, Yayın No: 5, Ankara Üniversitesi Ziraat Fakültesi, Eğitim, Araştırma ve Geliştirme Vakfi, Ankara.

Fidan H 2017.Amortisman Ömrünü (Faydalı Ömrü) Tamamlamış, Amortismana Tabi Tarımsal Varlıklarda Amortisman. Balkan ve Yakın Doğu Sosyal Bilimler Dergisi, 03(02):70-82

Günaydın G 2009. Koyun Yetiştiriciliğinin Ekonomi Politiği. U.Ü. Ziraat Fakültesi Dergisi, 23(2):15-32.
Gürsoy O 2009. Türkiye ve Avrupa Birliğinde Küçükbaş Hayvan Yetiştiriciliğinde Örgütlenme. U. Ü. Ziraat Fakültesi Dergisi, 23(2):79-95.

Kaymakçı, M. ve S. Engindeniz. 2010. Türkiye keçi yetiştiriciliği; sorunlar ve teknik-ekonomik çözümler. Ulusal Keçicilik Kongresi, 24-26Haziran, 2010, Çanakkale, s.1-25.

Karagölge, C., 2001. Tarımsal İşletmecilik-Tarım İşletmelerinin Analizi ve Planlanması. Atatürk Üniversitesi Ziraat Fakültesi Yayınları No:153, Erzurum.

Kıral T, Kasnakoğlu H, Tatlıdil F, Fidan H, Gündoğmuş E 1999. Tarımsal Ürünler için Maliyet Hesaplama Metadolojisi ve Veri Taban Rehberi. TEAE, Tarımsal Ekonomi Araştırma Enstitüsü, yayın no 37, ISBN 975-407-051-2

Koyuncu E, Pala A, Savaş T, Konyalı A, Ataşoğlu C, Daş G, Ersoy İE,Uğur F, Yurtman IY, Yurt HH 2006. Çanakkale Koyun ve Keçi Yetiştiricileri Birliği Üyesi Keçicilik İşletmelerinde Teknik Sorunların Belirlenmesi Üzerine bir Araştırma. Hayvansal Üretim, 47(1): 21-27.

Paksoy M 2007. Kahramanmaraş İlinde Süt Üretimine Yönelik Keçi Yetiştiriciliğine Yer Veren Tarım İşletmelerinin Ekonomik Analizi. Ankara Üniversitesi, Fen Bilimleri Enstitüsü, Tarım Ekonomisi ABD, Doktora Tezi, 146 p.

Sayin C, Mencet MN, Karaman S 2007.ImpactAssessment on MilkIncentivePolicies in Turkey: Antalya Province Case. Plenary paper prepared for presentation at the joint IAAE - 104th EAAE Seminar Agricultural Economicsand Transition:,What was expected, what we observed, the lessons learned." Budapest, Hungary. September 6-8, 2007

Yamane T 1967.Elemantary Sampling Theory, Printice-Hal.Inc. Engle Wood Clifts. NT. 